\title{
Efficient DNA Cleavage by Acridine Conjugates of Mono- and Dinuclear Cu(II) Complexes
}

\author{
Jung Hee Kim and Sam Keun Lee*

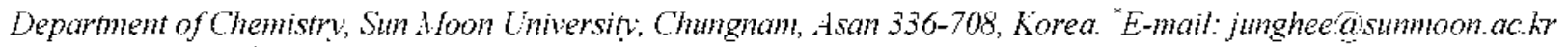 \\ ${ }^{\dagger}$ Department of Applied Chemistrv. Daejeon Cniversin, Daejeon 300-716, Korea
} Received June 11, 2008

Key Words : Dinuclear Cu complex. DNA cleavage. Acridine. Linker

There have been reported suitably designed, simple nonoand dinuclear metal complexes which are efficient in hydrolyzing phosphate esters including $\mathrm{DNA}{ }^{3}$ We have previously reported the dinuclear $\mathrm{Cu}(\mathrm{II})_{\mathrm{S}} \mathrm{L}$ l complex (L1: 1,3-bis (1,4.7triaza-I-cyclononyl)propane) efficiently hydrolyzed DNA. producing nicked and linearized DNA over the mononuclear CuL2 complex (L2: 1.4.7-triazacyclononane) ${ }^{2}$ We were interested in nuclease activity of the $\mathrm{Cu}$ complexes having DNA binding groups since it would provide valuable information in developing sequence specific artificial nucleases. Several acridine conjugates of mononuclear $\mathrm{Cu}$. $\mathrm{Zn}$ complexes had been reported. where strong binding through an intercalation of acridine moiety to DNA was the main factor for the nuclease activity. yet the cleavage mechanisms were not well established. ${ }^{3}$

In this study, we synthesized new acridine conjugates. L3 and $\mathbf{L} \mathbf{4}$ (Figure 1). Instead of using repeating alkỵl chain as used in most of model studies. ${ }^{3}$ polyethylene glycol unit was chosen for the linker since it allowed a significant increase in the length of the linker with relatively small change in the hydrophobicity of the molecule." Determination of the association constants for the binding and the cleavage rate measurements would allow for a detailed dissection of the factors responsible for the rate enhancement in cleaving DNA by the acridine conjugates of the $\mathrm{Cu}$ complexes.

\section{Experimental Section}

Materials. Amberlyst 21 resin was purchased from Alpha. All other chemicals were from Aldrich and used without
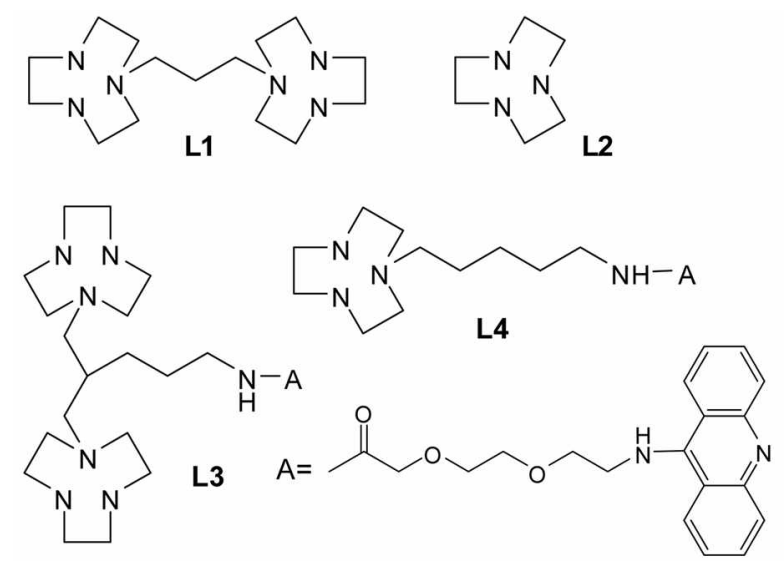

Figure 1. Chemical structures of the ligands. further purification. Supercoiled pCMV-Myc DNA was purchased from Clonetech. Labs (Mountain View, CA). Calf tymus-DNA was purchased from Signa and dialỵzed against water.

Synthetic procedure. ${ }^{1} \mathrm{H}$ and ${ }^{13} \mathrm{C}$ NMR spectrum were obtained from VARIAN UNITY-INOVA $300 \mathrm{MHz}$ spectrometer. Mass spectra were recorded on a Themo Finnigan AQA Lc-Mass. The ligands. L3 and L4 were synthesized by modified literature methods. $\mathrm{Cu}(\mathrm{II})$ complexes of L1-L4 were prepared according to the known method by mixing ethanolic solution of the ligand and 1.0-2.0 equivalents of $\mathrm{Cu}\left(\mathrm{NO}_{3}\right)_{2}$, respectively.

7-(5-\{2-[2-(2-Azido-ethoxy)-ethoxy]-acetylamino\}-penty])-[1,4,7]-triazonane-1,4-dicarboxylic acid di-tert-butyl ester (1): 7-(5-Amino-pentyl)-[1,4.7]-triazonane-1,4-dicarboxylic acid di-tert-butyl ester R1 (1.14 g. $2.75 \mathrm{mmol})^{7}$ and [2-(2-azido-ethosy)-ethoxy]-acetic acid ${ }^{8}(520 \mathrm{mg} .2 .75$ mimol) were dissolved in THF. DCC (680 $\mathrm{mg} .3 .3 \mathrm{mmol}$ ) was added slowly at $0^{\circ} \mathrm{C}$, followed by addition of catalytic amount of DMAP. The solution was stirred ovemight at room temperature. filtered and evaporated to dryness. After column chromatography $\left(\mathrm{CH}_{2} \mathrm{Cl}_{2}: \mathrm{MeOH}\right), 1.6 \mathrm{~g}$ of 1 was obtained as a syrup $(99 \%)$. ${ }^{1} \mathrm{H} \mathrm{NMR}\left(\mathrm{CDCl}_{3}\right): 6.82$ (bs. $\left.\mathrm{HH}\right)$, 3.97 (s. 2H), 3.70-3.66 (m. 6H). 3.46-3.38 (m. 6H). 3.30$3.16(\mathrm{~m}, 6 \mathrm{H}) .2 .60(\mathrm{bt}, 4 \mathrm{H}) .2 .45$ (bt. $2 \mathrm{H}) .1 .6-1.28(\mathrm{~m} .24 \mathrm{H})$. ESI MS (-): $\mathrm{m} / \mathrm{z} 584.8[\mathrm{M}]^{-}$.

2-[2-(2-Azido-ethoxy)-ethoxy]- $N$-[5-(4,7-di-tert-Boc-[1, 4 , 7]-triazonan-1-yl)-4-(4,7-di-tert-Boc-[1,4,7]-triazonan-1ylmethyl)-pentyl]-acetamide (2): R2 (1 g. $1.32 \mathrm{mmol}$ ) and [2-(2-azido-ethoxy)-ethoxy]-acetic acid ( $250 \mathrm{mg} .1 .32 \mathrm{mmol}$ ) gave 2 (1.l g. $1.19 \mathrm{mmol})$ as a synup $(90 \%)$. ${ }^{1} \mathrm{H}$ NMR $\left(\mathrm{CDCl}_{3}\right): 6.90$ (m. 1H). 3.97 (s, 2H), 3.70-3.67 (m, 6H). 3.60-3.08 (n. 18H). 2.69-2.5 (m, 8H), 2.5-2.37 (m. 2H), 2.37-2.21 (m, 2H). 1.62-1.32 (m, 40H), ESI MS: n/z 928.1 $[\mathrm{MH}]^{-}$

7-(5-\{2-[2-(2-Amino-ethoxy)-ethoxy]-acetylamino\}-penty])-[1,4,7]-triazonane-1,4-dicarboxylic acid di-tert-butyl ester (3): To 1 (1.3 g. $2.22 \mathrm{mmol})$ in $50 \mathrm{~mL} \mathrm{EtOH}$ was added $130 \mathrm{mg}$ of $10 \% \mathrm{Pd} / \mathrm{C}$. The solution was stirred underHydrogen pressure (50 psi) until no more starting material left. The mixture was filtered on celite and the filtrate was evaporated to dryness. After short column chromatography $\left(\mathrm{CH}_{2} \mathrm{Cl}_{2}: \mathrm{MeOH}=5: 1\right) .3(660 \mathrm{mg}, 1.18$ mmol) was obtained as a syrup (53\%). ESI MS: $\mathrm{m} / \mathrm{z} 560.5$ $[\mathrm{MH}]^{-}$

2-[2-(2-Amino-ethoxy)-ethoxy]- $N-[5-(4,7-$-li-tert-Boc-[1,4, 
7]-triazonan-1-yl)-4-(4,7-di-tert-Boc-[1,4,7]-triazonan-1ylmethyl)-pentyl]-acetamide (4): $2(1.1 \mathrm{~g}, 1.19 \mathrm{mmol})$ and $10 \% \mathrm{Pd} / \mathrm{C}$ produced $+(\mathrm{lg}, 1.11 \mathrm{~mm} / \mathrm{l})$ in quantitative yield. ESI MS: $\mathrm{m} / \mathrm{z} 901.7[\mathrm{MH}]^{-}$.

7-[5-(2-\{2-[2-(Acridin-9-ylamino)-ethoxy]-ethoxy\}-acetylamino)-pentyl]-[1,4,7]-triazonane-1,t-dicarboxylic acid di-tert-butyl ester (5): To $3(0.53 \mathrm{~g} .0 .95 \mathrm{mmol})$ in toluene $20 \mathrm{~mL}$ was added 9 -phenoxyacridine ${ }^{9}(257 \mathrm{mg}$. I equiv.). The reaction mixture was refluxed for $4 \mathrm{~h}$. The mixture was cooled to room temperature. After colunn chromatography $\left(\mathrm{CH}_{2} \mathrm{Cl}_{2}: \mathrm{MeOH}: \mathrm{Et}_{3} \mathrm{~N}=9: 1: 0.1\right) .5(0.42 \mathrm{~g} .0 .57 \mathrm{mmol})$ was obtained as a yellowish solid $(61 \%)$. ${ }^{1} \mathrm{H}$ NMR (acetone- $\left.d_{6}\right)$ : 8.40 (d. $2 \mathrm{H} . J=8.7$ ). 7.92 (d. $2 \mathrm{H} . J=8.7$ ). 7.69 (dd. $2 \mathrm{H} . J=$ 8.4 . 1.2). 7.39 (dd. $2 \mathrm{H} . J=8.4,1.2$ ). 7.24 (bs. $\mathrm{lH}$ ). 4.12 (t. $2 \mathrm{H}, J=5.4$ ). 3.95 (s. $2 \mathrm{H}$ ). 3.90 (t. $2 \mathrm{H} . J=5.4$ ), $3.55-3.45$ (m. $4 \mathrm{H}), 3.33-3.18(\mathrm{~m} .+\mathrm{H}) .3 .18-3.11$ (q. $2 \mathrm{H} . J=5.1) .2 .59(\mathrm{dd}$. $4 \mathrm{H} . J=4.8) .2 .44-2.36(\mathrm{~m}, 2 \mathrm{H}) .1 .48-1.23(\mathrm{~m}, 24 \mathrm{H}) .1 .25-$ $1.176(\mathrm{~m} .2 \mathrm{H})$, ESI MS: $\mathrm{m} / \mathrm{z} 737.6[\mathrm{MH}]^{-}, 369.6[\mathrm{M} \cdot 2 \mathrm{H}]^{2+}$.

2-\{2-[2-(Acridin-9-ylamino)-ethoxy]-ethoxy $\}-\mathrm{N}-[\mathbf{5}-(4,7-$ di-tert-Boc-[1,4,7]-triazonan-1-y])-t-(4,7-di-tert-Boc-[1,4, 7]-triazonan-1-ylmethyl)-pentyl]-acetamide (6): 4 (400 mg. $0.44 \mathrm{mmol}$ ) and 9-phenoxyacridine (120 $\mathrm{mg} .1$ equiv.) produced $6(220 \mathrm{mg} .0 .3 \mathrm{mmol})$ as a yellow foam $(68 \%)$ after column chromatography $\left(\mathrm{CH}_{2} \mathrm{Cl}_{2}: \mathrm{MeOH}: \mathrm{Et}_{3} \mathrm{~N}=9: 1\right.$ : 0.1 ). ${ }^{1} \mathrm{H}$ NMR (acetone- $\left.d_{h}\right): 8.47$ (d. $2 \mathrm{H} . J=8.7$ ). $8.0(\mathrm{~d}, 2 \mathrm{H}$. $J=8.7) .7 .7 \mathrm{l}($ dd. H. $J=8.4 .1 .5), 7.36(\mathrm{dd}, 2 \mathrm{H}, J=8.4 .1 .5)$. 7.34 (t, IH. $J=6.3) .4 .2(\mathrm{t}, 2 \mathrm{H}, J=5.1), 3.99-3.96(\mathrm{~m}, 4 \mathrm{H})$. 3.79-3.76 (m. $4 \mathrm{H}), 3.64-3.14$ (m. 18H). 2.64 (m. 8H), 2.472.41 (m. 2H). $2.3-2.2(\mathrm{~m} .2 \mathrm{H}) .1 .7-1.27(\mathrm{~m} .40 \mathrm{H})$. ESI MS: $\mathrm{m} / \mathrm{z} 1079.1[\mathrm{MH}]^{-} .540 .3[\mathrm{M} \cdot 2 \mathrm{H}]^{3+}$.

2-\{2-[2-(Acridin-9-ylamino)-ethoxy]-ethoxy\}- $\mathrm{N}-(\mathbf{5}-[\mathbf{1 , 4}$, 7]-triazonan-1-yl-pentyl)-acetamide (L3): 5 (170 mg. 0.16 mmol) was dissolved in $20 \mathrm{~mL}$ of $\mathrm{CH}_{2} \mathrm{Cl}_{2}: \mathrm{TFA}(\mathrm{l}: \mathrm{L})$ and stirred for $3 \mathrm{~h}$ at room temperature. After evaporation of solvent. the resulting syrup was washed with diethylether several times. L3 TFA salt $(175 \mathrm{mg})$ was dissolved in $6 \mathrm{~mL}$ of $\mathrm{CH}_{2} \mathrm{Cl} / \mathrm{MeOH}(5: 1)$, treated with Amberlyst 21 resin ( 10 equiv) for $1 \mathrm{~h}$. filtered and washed with $5-10 \mathrm{~mL}$ of $1: 1$ $\mathrm{CH}_{2} \mathrm{Cl}_{3} / \mathrm{MeOH} .{ }^{16}$ The combined filtrates were evaporated to give L3 (100 $\mathrm{mg} .0 .147 \mathrm{mmol}$ ) as a free base amine. ESI MS: L3-TFA: $\mathrm{m} / \mathrm{z} 537.6[\mathrm{MH}]^{+} .651 .6[\mathrm{M} \cdot \mathrm{TFA}]^{-} .269 .5$ $[\mathrm{M} \cdot 2 \mathrm{H}]^{2-},{ }^{1} \mathrm{H}$ NMR (acetone- $d_{6}$ ): L3: 8.42 (d, $2 \mathrm{H} . J=8.7$ ). 7.97 (d, $2 \mathrm{H} . J=8.7), 7.76$ (dd. $2 \mathrm{H}, J=7.6) .7 .44$ (dd, $2 \mathrm{H} . J=$ $8.4) .4 .40$ (s. $\left.\mathrm{H}_{2} \mathrm{O}\right), 4.14$ (t. $\left.2 \mathrm{H} . J=5.1\right) .3 .98$ (s. $\left.2 \mathrm{H}\right), 3.90$ (t. $2 \mathrm{H}, J=4.8), 3.74(\mathrm{~m}, 4 \mathrm{H}), 3.11(\mathrm{~m} .4 \mathrm{H}), 2.97-2.34(\mathrm{~m}$. $12 \mathrm{H}) .1 .47-1.25(\mathrm{~m}, 4 \mathrm{H}), 1.23-1.09(\mathrm{~m}, 2 \mathrm{H})$.

2-\{2-[2-(Acridin-9-ylamino)-ethoxy]-ethoxy\}- $N$-(5-[1,4, 7]-triazonan-1-yl-4-[1,4,7]-triazonan-1-ylmethyl-pentyl)acetamide (L4): $\mathbf{L} 4$ (100 $\mathrm{mg} .0 .18 \mathrm{mmol}$ ) was obtained from 4.TFA salt $(180 \mathrm{mg})$ as yellowish foam. ESI MS: L4.TFA: $\mathrm{m} / \mathrm{z} 678.8\left[\mathrm{MH}^{+} .792 .8[\mathrm{M} \cdot \mathrm{TFA}]^{-}, 340.1[\mathrm{M} \cdot 2 \mathrm{H}]^{3+}\right.$. ${ }^{1} \mathrm{H}$ NMR (acetone- $d_{6}$ ): L4: 8.44 (d. $2 \mathrm{H} . J=8.7$ ). 7.99 (d, $2 \mathrm{H}$. $J=8.7$ ). 7.78 (dd. $2 \mathrm{H}, J=7.8$ ). 7.45 (dd, $2 \mathrm{H} . J=8.7$ ). 4.40 (s. $\mathrm{H}_{2} \mathrm{O}$ ). 4.16 (t. $2 \mathrm{H} . J=5.1$ ). 4.03 (s, $\left.2 \mathrm{H}\right), 3.92$ (t. $2 \mathrm{H} . J=$ 5.4). 3.77 (m. $4 \mathrm{H}), 3.49$ (m. $2 \mathrm{H}), 3.21-2.27$ (m. $28 \mathrm{H}), 1.75-$ $1.53(\mathrm{~m} .2 \mathrm{H}) .1 .55-1.19(\mathrm{~m} .4 \mathrm{H})$.

$\mathrm{L} 1 / \mathrm{L} 3-[\mathrm{Cu}(\mathrm{II})]_{2}\left(\mathrm{NO}_{3}\right)_{4} \cdot \mathrm{xH}_{2} \mathrm{O}$ and $\mathrm{L} 2 / \mathrm{L} \downarrow-\mathrm{Cu}(\mathrm{II})\left(\mathrm{NO}_{3}\right)_{2}$ $\mathbf{x H}_{2} \mathrm{O}$. $\mathrm{Cu}(\mathrm{II})$ complexes of $\mathrm{LI}-\mathrm{L} 4$ were prepared by mixing ethanolic solution of the ligand and 1.1 or 2.1 equivalents of $\mathrm{Cu}\left(\mathrm{NO}_{3}\right)_{2}$, respectively. The resulting precipitate was filtered. washed with cold ethanol, diethylether. and dried in vacuo. In general. The solution $(5-100 \mathrm{mM})$ of $\mathrm{L} \times \mathrm{HCl}$ and $\mathrm{Cu}\left(\mathrm{NO}_{3}\right)_{2}$ were prepared separately in an appropriate buffer and mixed just before use. $\mathbf{L 1} \cdot[\mathrm{Cu}(\mathrm{II})]_{2}\left(\mathrm{NO}_{3}\right)_{4} \mathbf{X H}_{2} \mathrm{O}$ : ESI MS: $425.0\left[\mathrm{M}-4\left(\mathrm{NO}_{3}\right)\right] .611 .9\left[\mathrm{M}-\left(\mathrm{NO}_{3}\right)\right] \cdot \mathrm{L} 2-\mathrm{Cu}(\mathrm{II})\left(\mathrm{NO}_{3}\right)_{2}$ $\mathbf{x H}_{2} \mathbf{O}$ : ESI MS: m/z $\left.253.9\left[\mathrm{M}-\mathrm{NO}_{3}\right)\right]$ ]. L3-[Cu(II) $]_{2}\left(\mathrm{NO}_{3}\right)_{4}$ $\mathbf{x H}_{2} \mathrm{O}$ : ESI MS (-): $803.5\left[\mathrm{M}-4\left(\mathrm{NO}_{3}\right)\right], 864.73\left[\mathrm{M}-3\left(\mathrm{NO}_{3}\right)\right]$. $\mathrm{Lt}-\mathrm{Cu}(\mathrm{II})\left(\mathrm{NO}_{3}\right)_{2} \mathbf{x H}_{2} \mathrm{O}$ : ESI MS: $\mathrm{m} / \mathrm{z} 599.67\left[\mathrm{M}-2\left(\mathrm{NO}_{3}\right)\right]$, $661.4\left[\mathrm{M}-\left(\mathrm{NO}_{3}\right)\right]$.

Spectroscopic measurement. Absorption spectra were recorded on SINCO 3100 UV spectrophotometer (Seoul, Korea). Solutions (100 $\mu \mathrm{L}$ ) containing $10-20 \mu \mathrm{M}$ substrate were incubated in cuvett at $25^{\circ} \mathrm{C}$ for $10 \mathrm{~min}$. The $\mathrm{pH}$ of the solution was maintained with 10 mMHEPES $(\mathrm{pH} 7.0 . \mathrm{I}=10$ $\mathrm{mM} \mathrm{NaNO}$ ). About $1 \mu \mathrm{L}$ of an aliquot of CT-DNA stock solution (0.2-1 mM bp) was mixed. The DNA concentration was determined using extinction coefficient $\varepsilon_{258 \mathrm{~mm}}=6700$ $\mathrm{M}^{-1} \mathrm{~cm}^{-1}$. In general, binding of a substrate to DNA produces hypochromism. a broadening of the band and a redshift in the substrate absorption region. When the binding mode is homogeneous. the ground state association constant for the drug-DNA complex formation may be estimated from the changes in absorbance at a fixed wavelength. using the Benesi-Hildebrand equation. ${ }^{11}$

DNA cleavage. The DNA cleavage experiments were performed by the literature method. ${ }^{2}$ The cleavage products were analyzed in $1 \%$ agarose gels. The gels were stained in buffer containing $\mathrm{l} \mu \mathrm{g} / \mathrm{mL}$ ethidium bromide and the extent of DNA degradation was deternined by using volume quantitation method with KODAK EDAS 290 gel documentation system. The relative amounts of the different forms of DNA were determined by dividing absorbance intensity for a particular band by the total intensities of the each band in the same lane. The correction factor of 1.22 for form I DNA was utilized.

\section{Results and Discussion}

The acridine conjugates. $\mathbf{L 3}$ and $\mathbf{L}+$ were sy'nthesized from di-tert-butyl-1,4.7-triazonane-1.4-dicarboxylate via several steps including final 9-phenoxyacridine coupling (Scheme 1). Following deprotection of fully N-Boc-protected $\mathbf{L 3}$ and $\mathbf{L} 4$ by TFA $/ \mathrm{CH}_{2} \mathrm{Cl}_{2}$ gave the ligand TFA salts and treatment with ion exchange resin produced free bases $\mathbf{L 3}$ and $\mathbf{L} 4$, respectively. Synthetic order should be kept as shown in Scheme since coupling $\mathbf{R} 1$ or $\mathbf{R 2}$ with the linkeracridine conjugate gave the desired product in very low yield. Characterization of the intermediates was based on Mass data. ${ }^{1} \mathrm{H}$ and ${ }^{13} \mathrm{C}$ NMR spectra were complex since there existed several confonmers of N-Boc-protected tacn moieties.

Figure 2 showed UV/Vis absorption titration spectnum of the $\mathrm{Cu}_{2} \mathrm{~L} 3$ and $\mathrm{CuL} 4$ complexes with calf-thymus (CT) DNA at pH 7 and $25^{\circ} \mathrm{C}$. In the absence of DNA. 9-amino- 

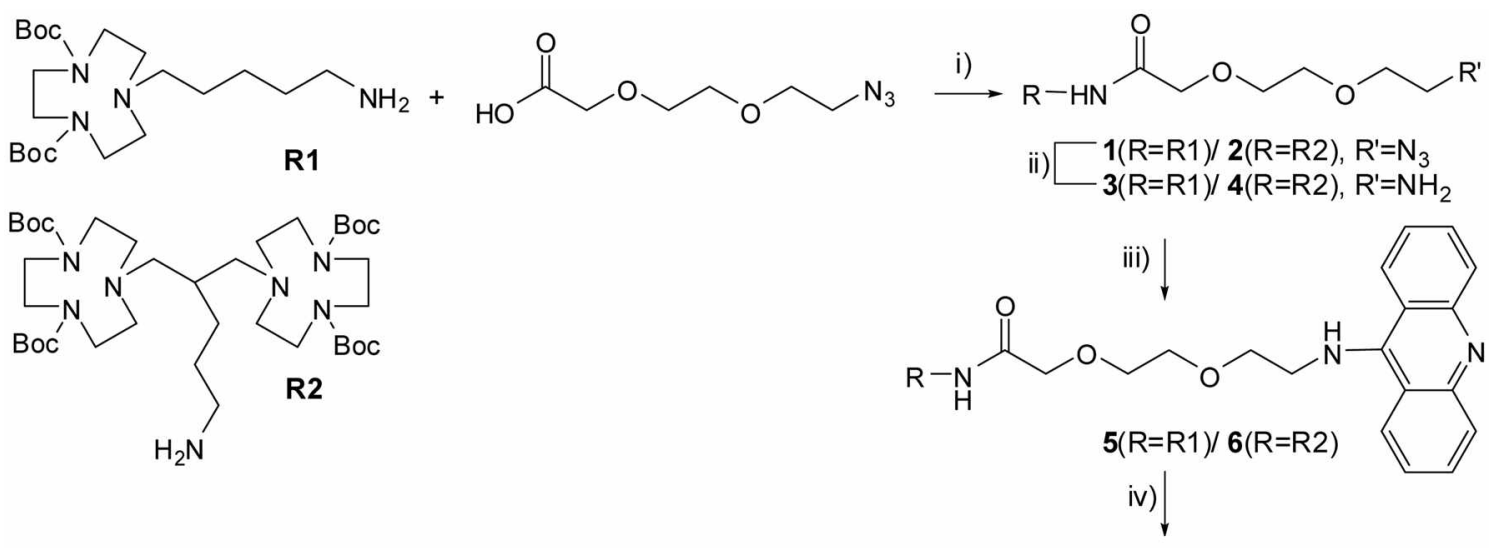

L3/L4

Scheme 1. Synthesis of ligands, $\mathrm{L} 3$ and L4. i) DCC, DMAP, $\mathrm{CH}_{2} \mathrm{Cl}$, $\mathrm{RT}$. ii) $\mathrm{H}_{2} / \mathrm{Pd}$, EtOH. iii 9-phenonyacridine, toluene, 60 " $\mathrm{C}$. iv ) TFA/ $\mathrm{CH}_{2} \mathrm{Cl}_{2}$, amberlvst 21 .

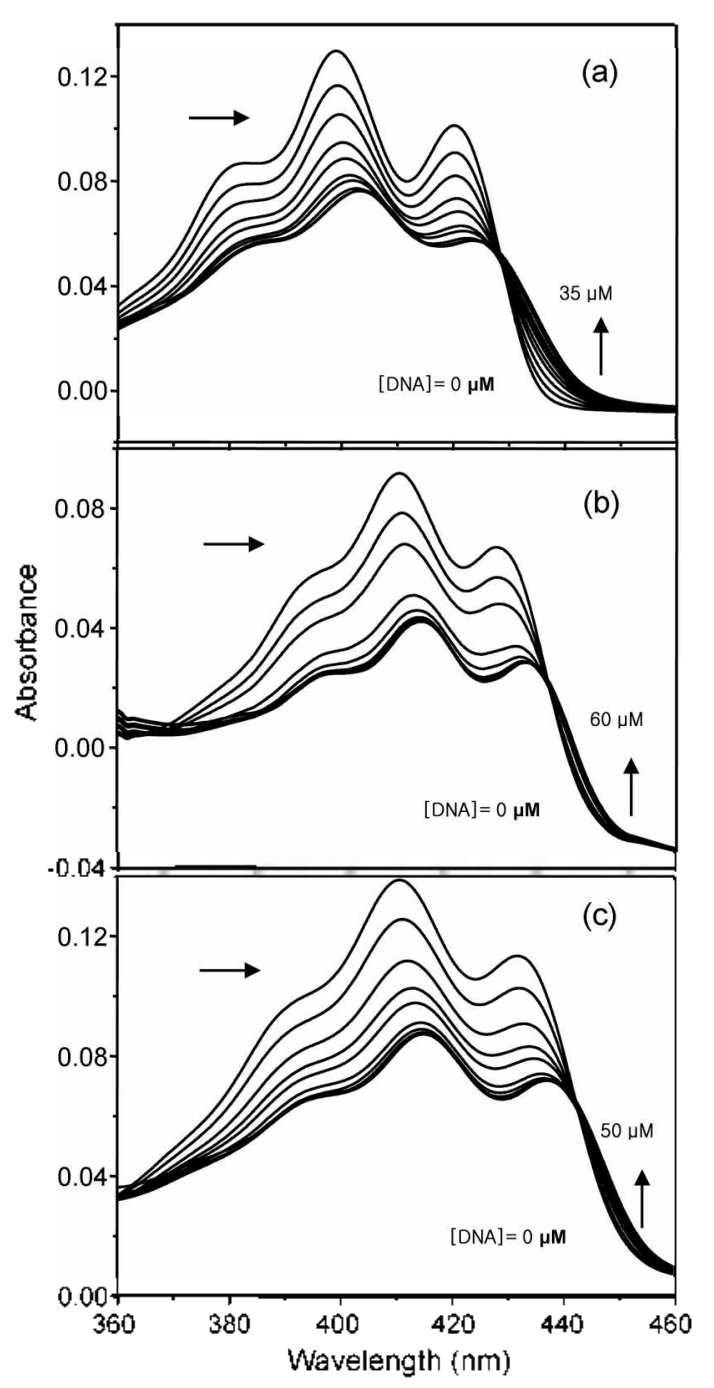

Figure 2. Absoption titration of CT-DNA by 9 -anniniacridine (a), the $\mathrm{Cll}_{2} \mathrm{~L} 3$ (b) and $\mathrm{ClL} 4$, (c) complexes at $\mathrm{pH} 7.0(10 \mathrm{mM}$ HEPES), $\mathrm{I}=10 \mathrm{mM} \mathrm{NaNO}_{3}$, and $25^{\circ} \mathrm{C}:[\mathrm{M}]=20, \mathrm{MM}$, [DNA] $=0$ $60 \mu \mathrm{M}$ to the anow direction

acridine showed its maximum absorbance at $382 \mathrm{~lm} .399$ int. and $420 \mathrm{~nm}$ and both $\mathrm{Cu}_{2} \mathrm{~L}_{3}$ and $\mathrm{CuL}_{4}$ complexes at

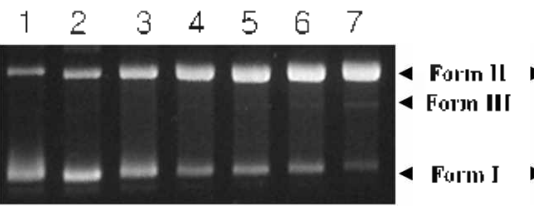

(a)

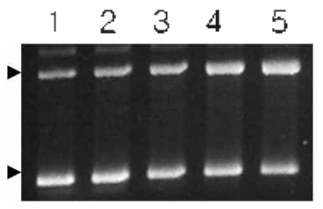

(b)
Figure 3. DNA (pCMV-Myc: $76, \ell \mathrm{M}$ ) cleavage at $\mathrm{pH} 7.3(10$ mMHEPES), $\mathrm{I}=10 \mathrm{mM} \mathrm{NaNO}_{3}$, and $30{ }^{\circ} \mathrm{C}: \mathrm{aj}+\mathrm{Cu}_{2} \mathrm{~L} 3(2, \mathrm{MM})$, lane $1-7: \mathrm{t}=0.1,1,3,5.5,8,11,24 \mathrm{H}$, respectively. b) $\mathrm{CuL}+(3.6$ $\mu \mathrm{M})$, lane $1-5: \mathrm{t}=1,6,11,18,24 \mathrm{H}$, respectively.

$392 \mathrm{~nm} .411 \mathrm{~nm}$, and $433 \mathrm{~nm}$. Attachment of $\mathrm{Cu}_{2} \mathrm{Ll}$ and $\mathrm{CuL} 2$ to 9-aminoacridine resulted in 10-13 rum red-shift suggesting interactions between the $\mathrm{Cu}$ and acridine moieties of the $\mathrm{Cu}_{2} \mathrm{~L} 3$ and $\mathrm{CuL} 4$ complexes. As the concentration of DNA increased, a 4-7 $\mathrm{nm}$ red shift for all absorption bands and $c a 40-42 \%$ hypochromism for 9-aminoacridine. $\mathrm{Cu}_{2} \mathrm{~L} 3$ and $\mathrm{CuL} 4$ complexes were observed. The extent of spectral changes for all three compounds indicated that they all associated with DNA through a similar binding mode. intercalation. ${ }^{12}$ The Benesi-Hildebrand plot was constructed from the change in absorbance at $435 \mathrm{~nm}$ for 9-aminoaridine. and at $450 \mathrm{~nm}$ for $\mathrm{Cu}_{2} \mathrm{~L} 3$ and $\mathrm{CuL} 4$ complexes. ${ }^{11}$ Association constants were calculated to be $3.4 \times 10^{4} \mathrm{M}^{-1}$. $1.9 \times 10^{5} \mathrm{M}^{-1}$ and $3.0 \times 10^{5} \mathrm{M}^{-1}$, for 9-aminoacridine, the $\mathrm{Cu}_{2} \mathrm{~L} 3$ and $\mathrm{CuL} 4$ complexes. respectively. Association constants for the acridine conjugates of the $\mathrm{Cu}$ complexes were not influenced significantly by the total charge on the catalytic group. rather depended on the length between the catalytic group and the acridine moiety as also shown in the previous experiment. $^{7}$

The cleavage reaction of supercoiled DNA by the $\mathrm{Cu}$ complexes was followed by monitoring conversion of plasmid DNA to relaxed circular (form II) and linear (form III) forms. if any (Figure 3). The decrease of form I to form II was plotted against time and it was fitted well with first order exponential decay curve (Figure 4). The extents of DNA cleavage by the $\mathrm{Cu}_{2} \mathrm{Ll}$ and $\mathrm{Cu}_{2} \mathrm{~L} 3$ complexes were proportional to the concentration up to $10-30 \mu \mathrm{M}$ and 


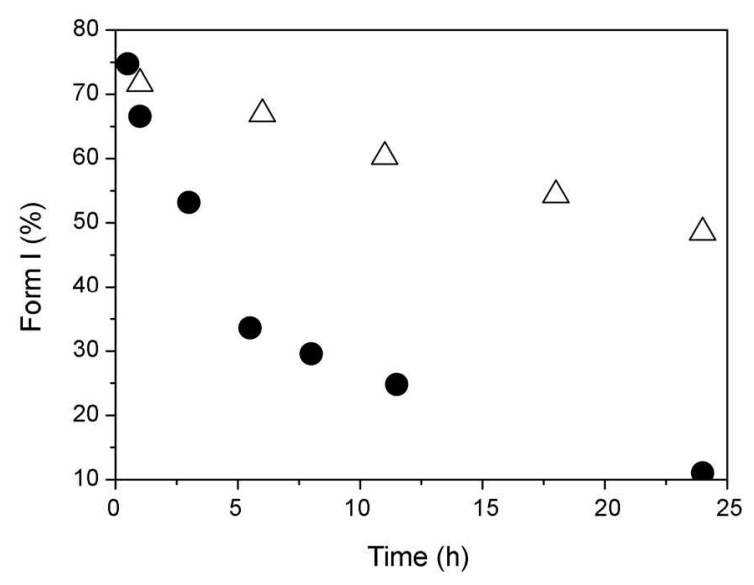

Figure 4. Plot of \% degradation of DNA (pCMV-Myc: $76, \mathrm{M})$ form I to form II by the $\mathrm{Cu}$ complexes at $\mathrm{pH} 7.3$ and $30^{\circ} \mathrm{C}$ : $\mathrm{Cu}=\mathrm{L} 3(2, \mathrm{MM}), \therefore$ : CuL $4(3.6 \mu \mathrm{M})$.

decreased thereafter (data not shown). The ionic strength dependencies on the cleavage rates by both complexes indicated strong electrostatic interactions with DNA. ${ }^{13}$

Fron Figure 4. the second order rate constants for degradation of form I to form II were obtained as $20.0 \mathrm{M}^{-1} \mathrm{~s}^{-1}$ and $1.3 \mathrm{M}^{-1} \mathrm{~s}^{-1}$ by the $\mathrm{Cu}_{2} \mathrm{~L} 3$ and $\mathrm{CuL}+$ complexes, respectively. ${ }^{1+}$ Since association constants of the $\mathrm{Cu}_{2} \mathrm{~L} 3$ and $\mathrm{CuL}_{4}$ complexes to DNA were about the same. the 20 fold rate enhancement observed could be ascribed to the cooperative role of two $\mathrm{Cu}$ ions in the $\mathrm{Cu}_{-} \mathrm{L} 3$ complex. The sumilar mechanism had been suggested in $\mathrm{Cu}_{2} \mathrm{Ll} / \mathrm{CuL} 2$ complexes mediated DNA hydrolysis reactions. ${ }^{2}$ At the moment. however. the coordination modes of the acridine conjugates of the $\mathrm{Cu}$ complexes to DNA and the induced conformational changes are yet to be investigated.

It is important to determine the association constants of the metal complexes to DNA and measure the rate constants for the DNA cleavage, since each step could be a key step for the simple metal complexes in hydrolyzing phosphates. In our study. the rate constants for the mono and dinuclear $\mathrm{Cu}$ (II) complexes having the same binding moieties to DNA were directly compared for the first time. With the similar binding constants to DNA. the dinuclear $\mathrm{Cu}_{-} \mathrm{L} 3$ complex was far more efficient than the corresponding mononuclear CuL4 complex in cleaving DNA. suggesting that cleavage of phosplate diester backbone of DNA was the key step in hydrolyzing DNA.

Acknowledgments. This work was supported by the Korea Science and Engineering Foundation (R04-2003-00010097-0).

\section{References}

1. (a) Strater. N. S.: Lipscomb. W. N.: Klabunde. T:: Krebs. B. Angew. Chent. Int. Ed. Engl 1996. 35. 2024. (b) Cowan. T. A Curr. Opinion in Chem. Biol 2001. 5. 634. (c) Liu. C.: Wang. M.: Zhang. T.; Sun. H. Coord. Chem. Rev 2004. 248. 147 . (d) Striegler S. Cwm Org Chom 2007, 11, 1543. (e) Lu, Z; Liu, T. C.: Neverov, A. A.: Brown. R. S. J. Am. Chem. Chem, 2007, 129, 11642

2. (a) Kiml. T. H.: Kim. S. H. Chent Lett. 2003. 32.490 . (b) Kim. J. H.: Lee. W. S. Jang. T. K. Bull. Konew Chent. Soc. 2004. 25. 410

3. (a) Sissi. C.: Rossi. P.: Felluga. f.: Formaggio. F.: Palumbo. M.: Tecilla. P: Toniolo, C: Scrimin, P. J. Am. Chem. Chem. 2001. 123. 3169. (b) Boldron, C.: Ross, S. A.; Pitie. M.; Meunier, B. Bioconjugate Chem. 2002. 13, 1013 . (c) Havashi, K. Nakajima. R.: Kiyosawa. I.: Ozaki. H.: Sawai. H. Chent. Lett. 2004. 33. 684. (d) Hirchama. T.: Arii. H.: Chikira. M. J. horg. Biochent. 2004, 94. 1778. (e) Bossegia. E.: Gatos. M:: Lucatello. L:: Mancin. F.: Moro. S.: Palumbo, M.: Sissi, C.: Tecilla. P.: Tonellato, U. Zagotto, G. J. Am. Chem. Soc. 2004, 126, 4543. (t) Chen. X; Peng. X.-J.: Wang. J.-Y; Wang. Y; Wu, S.; Zhang. L.-Z.: Wu. T:; Wu. Y.-K. Eur. J. horg. Chent 2007. 5400 .

4. McNight. R. E.: Zhang. J.: Disson. D. W. Bioorg Med Chen. Letf. 2004. 1H, 401

5. Weisman, G. R.; Jonson. V; Fiala. R. E. Tetrahedron Lett. 1980. 21. 3635 .

6. (a) Haidar. R. H.; Ipek. M.: Dasgupta, B.; Yousef, M.; Zompa, L J. Inorg. Chent 1997. 36. 3125. (b) Dasgupta. B.: Katz. C.: Israel. T.: Watson. M.: Zompa. L. J. Inorg Chin. Acta 1999. 292.172.

7. Kim. J. H.: Youn. M. R.: Lee. Y.: Kim. T. M.: Kim. S. K. Bull. Korean Chem. Soc. 2007, 28, 263.

8. Jeong, S. W.: O'Brien, D. F. J. Org. Chem. 2001. 66, 4799

9. Kuzuya A.: Machida, K:; Mizoguchi, R; Komiyama, M. Bioconituate Chent 2002. 13.365.

10. Stinivasan. N.: Yurek-George. A.: Ganesan1. A. Holecular Diversint 2005. 9.291.

11. Benesi, H. A. Hildebrand. J. H. J. Am Chem. Soc. 1949. 71. 2703.

12. Modukuru. N. K.: Snow, K. J.; Perrin, Jr.. B. S.: Thota, J.; Kumar, C. V. J. Phus. Chem. B 2005, 109, 11810.

13. Pamatong. F. V.: Detmer. III. C. A.: Bocarsly. T. R. J. Am. Chen. Soc. 1996.118 .5339 .

14. Instead of the tirst order rate constant ( $k$ ) obtained from Figure 4. the second order rate constant $(\mathrm{k}[\mathrm{Cu}]$ ) was used for the direct comparison of efficiency since working concentrations of the catalysts were not the same. 